\title{
Broadening and Narrowing Horizons in Zoë Wicomb's The One That Got Away
}

Fiona McCann

\section{(2) OpenEdition \\ 12 Journals}

Electronic version

URL: https://journals.openedition.org/ces/8305

DOI: $10.4000 /$ ces.8305

ISSN: 2534-6695

Publisher

SEPC (Société d'études des pays du Commonwealth)

\section{Printed version}

Date of publication: 1 September 2010

Number of pages: $55-66$

ISSN: 2270-0633

\section{Electronic reference}

Fiona McCann, "Broadening and Narrowing Horizons in Zoë Wicomb's The One That Got Away",

Commonwealth Essays and Studies [Online], 33.1 | 2010, Online since 11 December 2021, connection on 20 January 2022. URL: http://journals.openedition.org/ces/8305 ; DOl: https://doi.org/10.4000/ces. 8305

\section{cc) (†)}

Commonwealth Essays and Studies is licensed under a Licence Creative Commons Attribution - Pas d'Utilisation Commerciale - Pas de Modification 4.0 International. 


\section{Broadening and Narrowing Horizons in Zoë Wicomb's The One That Got Away}

In her most recent work of fiction, The One That Got Away (2008), a short story cycle of both place and character, Wicomb continues her exploration of the limits of the short story genre. This article shows how, as characters slip in and out of stories, and as the topographical, cultural and lexical signifiers of one place are blended with or usurp those of the other city, Wicomb gradually interrogates the potentially enriching yet often limited cultural exchanges between Capetonian and Glaswegian characters. A study of her formal reflection of the aborted or confused communication between characters will lead to an analysis of her interrogation of the writing process.

T T 7 th the publication in 1987 of the short story collection You Can't Get Lost in Cape Town, Zoë Wicomb immediately received positive critical attention. The work was quickly dubbed "the first book-length work of fiction set in South Africa by a coloured woman writer," (Sicherman 187) an appraisal which, although a bit of a mouthful, places Wicomb in the lineage of Bessie Head, who, if one is to continue dealing in superlatives, was the first coloured South African woman writer to publish a work of fiction. Unsurprisingly perhaps, when one considers that Head was exiled from her native South Africa and lived in Botswana, the politics of place are significant in her work. ${ }^{1}$ Wicomb, who has chosen to live in Scotland, is also concerned with place and "the construction of home as problematic space," thereby "call[ing] into question the notion of stable, continuous identities." (Boyce Davies 65) Wicomb's interrogation of stable identities extends beyond a mere thematic concern: her first work of fiction already experiments with some of the generic codes of the short story, blurring the boundaries between the novel and the short story cycle. In addition, her first novel, David's Story (2000), playfully foregrounds the illusion of history as a grand narrative, rendering the frontier between fact and fiction porous. Although less overtly playful in its approach, her second novel, Playing in the Light (2006), also focuses on fluctuating identity politics, particularly in relation to coloured communities. It therefore comes as no surprise that her most recent publication, the short story cycle The One That Got Away (2008), should continue to delve into the question of identity, giving it prominence as a central theme, and also experimenting with the malleability of the genre.

The One that Got Away, however, marks a new departure in Wicomb's fiction as, although her past works have focused on elements of cross-cultural exchanges,

1 Desirée Lewis, for example, has highlighted 'the primary symbolic meanings of exile and geographical relocaton' in Head's novel When Rain Clouds Gather. (Lewis 129) 
their context has almost exclusively been South African. ${ }^{2}$ This latest collection is a short story cycle of both place and character (Lynch 20), but the setting oscillates between Cape Town and Glasgow. In her constant straddling of two countries in these stories, Wicomb explores once again the notions of identity and métissage with a view to highlighting how enmeshed identities are, both locally and globally, at this period in time when, as Édouard Glissant has suggested, wandering is the very thing that enables us to settle (Glissant 63 ). ${ }^{3}$

This paper purports to show how, as characters slip in and out of stories, and as the topographical and lexical signifiers of one place are blended with or usurp those of the other city, Wicomb gradually questions both the potential and the limits of cultural exchanges between Capetonian and Glaswegian characters. A study of Wicomb's rapid shifts in focalisation and mises en abyme will demonstrate how these devices reinforce on a formal level the aborted or confused communication between characters, while an analysis of her playful postmodern techniques will show how she foregrounds the act of representation. This will ultimately lead to a consideration of this collection as a significant contribution to the creation of new horizons within the short story genre, the boundaries of which can perhaps endlessly be stretched.

To Gerald Lynch's assertion that the short story cycle in the Canadian context is "a form that allows for a new kind of unity in disunity, reflecting a fragmented temporal sense," (18) one could add that this sub-genre also lends itself to the representation of spatial continuity and discontinuity. Although Lynch is concerned with "the short story cycle [as] a distinctly Canadian genre," (xv) he implicitly points towards the attraction of the short story cycle for writers from other postcolonial countries formed amidst tensions between several cultural allegiances. Indeed, in today's global village, one might consider the short story as particularly apt for explorations of national and transnational cultural collisions, highlighting simultaneously "the one and the many" and offering "a kind of geo-political fictional linkage of abiding bonds and creative gaps." (Lynch 190) Perhaps the most striking element in Zoë Wicomb's cycle is the inclusion of and interaction between characters from two different continents, the communication between whom is fraught with confusion and misunderstanding. By loosely linking these characters together and by varying their points of view, both within and between stories, Wicomb accentuates the complexity of communication not just between characters from different ethnic, linguistic, cultural and socio-

2 For instance, the years that Frieda Shenton, the protagonist of You Can't Get Lost in Cape Town, spends in England are elided. Wicomb has herself commented on her desire to highlight "the negative semantic space that is [her] protagonist's life in England." (Meyer \& Olver 185) The main character of Playing in the Light travels to Scotland, but there is no real possibility of cultural exchange due to this character's limitations and the overall setting of the novel is predominantly South African.

3 The original reads as follows : "L'errance, c'est cela même qui nous permet de nous fixer." 
economic backgrounds, but also between different generations within the same family. Although the geographical scope remains modest, South Africa and Scotland being the main settings, the result is a mosaic of entangled identities spawned from colonial and postcolonial encounters.

The story entitled "Nothing Like the Wind," placed fourth from the end of the collection of twelve stories, is the first story not to adhere to the principle of characters moving from one story to another. ${ }^{4}$ This obvious change highlights the absence of familiarity, which has gradually built up in the preceding stories. It also reflects the alienation of the protagonist, Elsie, whose point of view is privileged throughout. A teenage girl, Elsie has recently come from South Africa to live in Scotland after the demise of apartheid and the death of her paternal grandmother, a change so profound that it upsets all members of the family in different ways. Instead of finding a solution for their cold house, her father begins to obsessively collect brass objects; her brother starts to rape her on a regular basis. Elsie herself, faced with the difficulties of immigration, dreams of an elusive freedom from the gender, class and geographical prison she finds herself in.

Although this story is set in Glasgow, Elsie's meandering thoughts often create a superimposition of the Karoo (where she lived prior to her move) onto her new environment. The first sentence of the story, "The sound of traffic is nothing like the wind" (135) appears to refute any similarities between the two places, and yet the intermingling of the two will recur throughout the story, emphasising the fluctuating notion of home. Elsie, used to her own vernacular in which words like "bedondered" (135) flourish, has trouble incorporating new lexical elements into her vocabulary: "she must remember to say traffic lights" and not "robots"; "Not gnats. In Scotland they are called midges," (137, 142). These lexical differences (in relation to the Glaswegian norm) contribute to her alienation upon her arrival. Interestingly, however, Elsie does not have the adequate words to recount experiences which are new to her since her arrival in Scotland. The word "rape" is never used in the description of her brother's routine violation of her: "Bothered by his thing grown stiff and sticky, he creeps at night out of his windowless cupboard that accommodates nothing other than a bed. [...] He creeps into her room, and bothers her with his thing. Which is mildly interesting, repellent." (142) The repetitive use of the same verbs "creep" and "bother" and the unspecific noun "thing" highlight the reduced vocabulary with which she tries to make sense of this new experience. The use of the verb "bother" is particularly striking, as it seems more appropriate for dealing with mild pestering than sexual violence. That Elsie does not have the words to deal with her experience is underlined by the almost paradoxical association of "interesting" and "repellent," separated only

4 This story, first published in 1990, is one of five to have been published independently of the collection. Four of these stories are placed at the end of the collection, but one of them, "Boy in a Jute-Sack Hood," placed at the beginning of the book, has been incorporated into the cycle, through the main character. 
by a comma and qualified by the incongruous use of "mildly." This is reinforced at the end of the paragraph through the assertion: "Elsie hates him," (142) the categorical and forceful nature of which is in opposition with the equivocation previously expressed.

The family's difficulty in adapting to their new life is not limited to lexical complexity. Although the story is essentially one of a double tragedy (the private sexual abuse to which Elsie is subjected and the very public sexual assault and murder of Freddie, Elsie's brother-rapist), one of the most significant elements of the story is the discrepancy between claiming oneself as Scottish (or of Scottish descent) in Apartheid South Africa, and claiming oneself as Scottish in Scotland when one has just arrived from South Africa, the nuances of social class taking on a whole new dimension. Elsie's father initially employs a charwoman (until he realises they cannot actually afford this), and when he presents his brass collection to her to be cleaned, her puzzled look and humorously dismissive response, "No chance wee man," (138) highlight the father's failure to grasp the intricacies of social hierarchy in this new environment. Likewise, Elsie's inability to comprehend the shift in her father's self-identification as first English and then Scottish ("at home they had always been English, and here, she soon came to understand, $[\ldots]$ that was quite different" 143) highlights the complex levels at work in identity politics within the colonial centre, levels which are melded together into a homogenous oneness in the collective imaginary of those who have settled in the erstwhile colonies. In a similar way, the main character of the story "In the Botanic Gardens," Dorothy, who has come to Glasgow following the mysterious disappearance and presumed death of her son, who was studying there on a scholarship, has trouble deciphering a handwritten message on a Clydesdale banknote: across a stereotypical colonial representation, the following sentence is scrawled, "if dat bastard Geldof don't git 'ere soon I goes eat dat camel." (168) Dorothy takes the text literally as an encoded message addressed to her, remembering that Biblical parables "meant something other than what the actual words said." (168) She erroneously interprets (Bob) Geldof as a substitute for her son's name, associating it with money ("geld meaning money"), and taking the expletive as a comment on her son's illegitimacy. This superimposition of the metaphorical onto the literal, aside from being comical, highlights the intricacies of communication in different cultural contexts and the ever shifting horizons of language(s).

The narrative choice consisting of privileging the naive adolescent Elsie's point of view in "Nothing Like the Wind," and that of the naive Dorothy in "In the Botanic Gardens," enables Wicomb to pinpoint not only the variability of semantics in different contexts, but also to focus on a reversal of narrow-minded socio-cultural expectations. Elsie's father, it is implied, leaves South Africa after his mother's death because of the demise of apartheid and the impending end of the privileges of being white. He holds the political changes responsible for his mother's death and "pack[s] in this whole thing and start[s] again in another 
place, somewhere more civilised." (140) The use of the dismissive euphemism "this whole thing" barely masks his latent racism and homophobia, and Glasgow becomes the "civilised" place to fall back on. However, the violence with which the family has never been in contact in South Africa erupts in Glasgow, when Freddie, who sexually assaults his sister, is in turn sexually abused and strangled by a man with "flaming red hair," (143) Wicomb thus interrogating the fallacy of so-called European "civilisation" versus the "savage" African ex-colonies. The recourse to stereotype in the depiction of the murderer further complicates the question of the representation of the Other. Elsie is brought to "understand that the hair stood for uncontrollable passions," (143) the suggestion here being that her father believes the killer is somehow to be exonerated because of a Celtic appearance which stands for a specific temperament, so bound up is he in racial stereotypes and predetermination.

Ultimately, the potential for growth in this new environment is thwarted by Elsie herself. Her repetitive checking that the windows and doors are tightly shut and bolted highlights her self-imprisonment, and stands in opposition with the vast expanses of the Karoo, which she consistently refers to as "home." Indeed, Elsie's recurrent, sometimes almost imperceptible mental shifts from Glasgow to the Karoo highlight the discrepancy between the prison in which she physically finds herself and the freedom which her old life in the Karoo represents: "Elsie checks that the door is safely barred against the wind, Granny's kitchen door." (139) Her refusal to open the door to the boy who has asked her to the end-ofyear dance, and her decision to crawl into bed instead, poignantly invite us to interpret the story's final image of "an ark, light as a paper boat, drift [ing] down the Great Western Road with the sail of Granny Reid's green shawl flapping in the distance" (145) as a metaphor for Elsie's inability, or lack of desire, to grasp the (albeit limited) possibilities offered to her in this new environment. The "Great Western" world is perceived as restrictive by Elsie, and through the protagonist's constant superimposition of landmarks of her life in the Karoo onto this new life in Glasgow, Wicomb is clearly undermining the "Greatness" of the Centre.

The strange and the familiar are also blended together in "In the Botanic Gardens" with a view to calling attention to the confirmation or reversal of cultural expectations. Inside the Botanic Gardens, Dorothy's feelings of confusion are initially dissipated by her encounter with flowers which she recognises, the very localised personification of which ("made up like platteland girls in Town, sitting pertly behind glass, if you please," 69) highlights her familiarity in these unfamiliar surroundings. The amalgamation of the strange and the familiar continues when a young child mistakes Dorothy, resting in front of the Papua New Guinea hut, for "a Papoo person," (170) allowing Wicomb to emphasise and gently mock the narrow cultural horizons between people of different cultures and the tendency to homogenise people according to skin colour. At the same time, since the implication is that the disappearance of Arthur, Dorothy's son, is linked to his involvement in politics, the suggestion very clearly is that although Dorothy's 
involvement with Glaswegians is fraught with difficulty and misunderstanding, the pro-Apartheid South African state has had no difficulty locally negotiating Arthur's death, ${ }^{5}$ a fact which renders Dorothy's quest for her lost son all the more poignant.

The confused or aborted communication experienced by both Elsie and Dorothy in strange new environments is not extended into the narrative pattern itself, the privileging of both characters' points of view through free indirect discourse creating humour and pathos. Other stories in this collection, however, contain shifting points of view, which reflects on a formal level the potentially constructive, yet often limited exchanges between characters from different geographical, class and linguistic horizons. The remainder of this article will focus on two of these stories in particular, "Neighbours" and "Trompe l'œil," demonstrating not only how Wicomb's narrative choices mirror the difficulties inherent in negotiating the differences both between characters from different cultures and between characters from the same culture, but also how her recourse to a postmodern foregrounding of the writing process contributes to her overall interrogation of these questions.

These two stories are linked through the character of Ben, a black South African woman who was an MK militant ${ }^{6}$ in the past and who moves in next door to Jeff n'Marie, the eponymous "neighbours" of the first story. She is also the mother of Roddy, a character in "Trompe l'œil" whose own fictional narrative is embedded within that story. Although "Neighbours" is set in Glasgow, "Trompe l'œil" is set in both Italy and South Africa, and the narrative style of both stories bears the traces of the cultural collisions which result from these encounters. The conversational tone and the colloquial expressions present from the opening of "Neighbours" immediately alert the reader to the viewpoint through which the story is narrated: that of Jeff n'Marie, the spelling and yoking together of their names simultaneously reflecting their view of themselves as inseparable and mocking them as some sort of comic double act. Jeff n'Marie's self-satisfied, regular and ultimately, as the story reveals, vacuous lifestyle is upset by the arrival next door of Ben and her son, upon whom the Scottish couple bestows a number of unpleasant stereotypes, purely on the basis of what they see: Ben's son is "no doubt sponging off his mother," "that idle yob"; Ben herself is "a single parent" and "no spring chicken" whose saving grace "is that she does speak nicely, not your common type." (82, 88, 82, 87 respectively) The abundance of clichés, both here and throughout the story, emphasises Jeff n'Marie's limited horizons,

\footnotetext{
5 This story was first published in 1991 and appears to be set before the beginning of the end of Apartheid in 1990.

6 Umkhonto we Siswe (MK), which was the military wing of the African National Congress (ANC), carried out numerous attacks within the borders of South Africa and fought alongside allies against the oppressive regimes of neighbouring countries between the early 1960s and 1990.
} 
culturally and linguistically, and this is made all the more apparent by occasional sophisticated interventions by the narrator. Taking great pride in their own garden, Jeff 'n'Marie are concerned at the lack of interest their new neighbour takes in her overgrown garden: "having scrimped and saved, they do not deserve this; [...] The woman's views themselves are like weeds that will multiply wantonly and invade the artful order of herbaceous borders." (84) Here, the clichéd language of the first sentence ("scrimped and saved") is obviously at odds with the extended metaphor which unfurls in the second sentence. The resulting dissonance highlights "the intentional dimensions, that is, the denotative and expressive dimensions of the 'shared' language's stratification" (Bakhtin 289). With it, Wicomb subtly draws attention to the non unitary nature of language in order to uncover the limited horizons of the characters Jeff 'n'Marie. These characters' over-reliance on idiomatic expression, their tendency to let their sentences trail off, unfinished, both reveal the emptiness of their lives so poignantly shown at the end of the story through Jeffs dementia and question: "But what do we do in our home?" (98) This heteroglossia and the substantial gap between the two utterances, heightened by the overly-sophisticated lexical elements of the second sentence, also enable Wicomb to draw attention to the distance her narrator creates with these characters, mocking their limited and parochial viewpoint.

Abrupt shifts in point of view in this story also amplify the multiplicity of identities converging within a specific space, and point to the endurance of what Patrick Chamoiseau and Édouard Glissant have called the "identity wall." Once useful in order to reconstruct groups which were victims of domination and violence, but now a pretext behind which one can hide in order to avoid contact with the Other, the identity wall no longer protects, and rather tends to lead to regression, an insidious asphyxia of the mind, and the loss of self (Chamoiseau \& Glissant 11). ${ }^{7}$ When Jeff's dementia manifests itself at the end of the story, the sudden juxtaposition of Marie's and Ben's points of view highlights the incommensurability of their lives despite the momentary convergence of their paths: "Marie looks at him blankly. Tears well up in her eyes, tears of selfpity and incomprehension. Surely she does not deserve this. She would rather he spoke of Saturday afternoon activity after all, than this doolally behaviour." (98) Once again, the shift from the narrator's critical distance to free indirect discourse emphasises Marie's emotional limitations reflected in the familiar register and childish euphemism used. Ironically, what she refers to colloquially as "doolally behaviour" is, in fact, Jeff's lucid realisation that their lives amount to nothing. Marie's self-pity is in stark contrast with Ben's reflections concerning her situation:

They're not her sort of people; they're only neighbours, for God's sake. But just as she decides that she has no choice but to deal with the man, Ben's own head

7 The original reads as follows: "[Le mur identitaire] ne protège plus, n'ouvre à rien sinon à l'involution des régressions, à l'asphyxie insidieuse de l'esprit, à la perte de soi." 
floods with confusing images - of police with dogs, of crouching in the bush with AK-47s and the acrid smell of fear, of Rueben as a baby crying day and night, and Roddy packing his bags, having had enough, whose words pound in her ears: Your world is not mine. I can't live with your past. Yes there are many worlds, and to return to this one Ben has to scale a high wall, but she slips back, repeatedly, until, after a superhuman effort she reaches the top, back to Bilsland Road where she dredges from her memory a scene from the bedroom window. (99)

The breadth of experience which the memories Ben is overwhelmed by testify to are markedly different and rather more complex than the poverty of Marie's existence. The unexpected associations of motherhood and guerrilla warfare and the range of emotions called up by these episodes of her life, highlighted through free indirect discourse, point towards the multi-dimensional layers of Ben's life as opposed to the one-dimensional aspect of Marie's life. Interestingly, however, it is Ben who attempts to establish contact with these neighbours with whom she feels no affinity, suggesting that it is the wide scope of her experience which enables her to do so. The sudden intrusion of her son's words is particularly significant in terms of positing the multifarious divergent worlds which constantly collide not always happily - even within families. His refusal to engage with his mother's politically committed life is at odds with her attempt, in spite of herself, to interact with these neighbours who are "not her sort of people." The striking imagery, the elaborate nature of which signals once again a subtle shift from free indirect discourse to an intervention by the narrator, clearly underlines the difficulties of cultural interaction, and the Sisyphean conceit, along with the hyperbole and the constant rupture reflected in the punctuation, all contribute to stressing the laboriousness of communication and the heteroglossic dimension of all inter-and intracultural encounters. Ben, the migrant figure, succeeds in scaling the (identity) wall, while Jeff n'Marie's inability to do so results in an insidious asphyxia of the mind, and the loss of self, reflected in Jeff's disorientation at the end of the story.

As the very title of the story suggests, "Trompe l'œill" contains multiple diegetic layers, a narrative choice which enables Wicomb to simultaneously foreground the writing process and present conflicting cross-cultural communication. The story oscillates between the points of view of Gavin, an arrogant white South African university professor and his timid, self-effacing wife, Bev, and focuses on their stay at an Italian Foundation for artists, writers and scholars. During this stay, they meet Roddy (a young Scottish writer of fiction and the son of Ben in the story "Neighbours"), parts of whose short story are embedded within the narrative in italics. As the story progresses, Gavin and the reader gradually discover Roddy's fictional representation of his interaction with the couple in Italy, a representation which is interspersed by analepses (often from Bev's point of view) relating the stay at the study centre in Liguria.

The interplay of layers - diegetic (the main story), extradiegetic (the narrator's framing of that story) and metadiegetic (the story within the story), to take up Genette's terminology (Genette 237) - provides alternative versions of the 
relationships established between the main characters. While the story as a whole broadens the horizons of "a single story," the dangers of which Chimamanda Adichie has guarded against (Adichie 2009), it paradoxically highlights the narrow horizons of individual characters. The story opens with an excerpt from Roddy's short story, and the italicisation of this text, followed by Gavin's dismissive response to what he (and the reader) is reading, renders it immediately clear that this "embedded text that presents a story which [...] resembles the primary fabula," although seemingly disconnected from it, will come to function as a "sign of the primary fabula." (Bal 56) Wicomb's use of a "mirror-text" as Bal terms mise en abyme ( $\mathrm{Bal}$ 58) does not, however, serve either of the purposes the latter identifies in her analysis: it is neither exclusively predictive, nor retrospective, but both, simultaneously. If the significance of the extract from Roddy's short story is veiled at the beginning, it quickly becomes obvious that it "serves as directions for use" [and] "contains a suggestion how the text should be read." (Bal 59)

In this short story, Wicomb furthers her exploration of the porous boundaries between fact and fiction, as it gradually dawns on Gavin, himself a fictional character, that he is in fact a character in Roddy's story, which presents him in a very unflattering light. The traits in Gavin's character, which are emphasised in the story he is reading thanks to the constant focalisation of the young man in denim, a fictionalised version of Roddy himself, are already present in the primary fabula. The privileging of Gavin's point of view quickly reveals his arrogance, snobbery and racism: writers of fiction cannot compare with historians and the thinking required for their research. Positive discrimination, imported from Britain by "colonial mimic" (132) has led to "shoddy scholarship" and South African universities "no longer [being] the places of learning that they once were." (120) Certain idiosyncratic locutions, such as the repetition of "No, no, no" or "Of course" at the beginning of sentences also point to the overlap between "the blazered man" in Roddy's story and Gavin. If the extracts from Roddy's story do not therefore initially enlighten the reader of "Trompe l'œil," they do alert Gavin to "the pathetic characterisations, the heinous misrepresentation" of himself (132).

Rather than serving a specifically predictive or retrospective purpose, the inclusion of Roddy's embedded narrative raises questions about representation and the representation of representation. The trompe l'œil of the title at first appears to relate to the architectural specificity of Luguria. Yet Wicomb, who often resorts to ekphrasis (particularly in David's Story ${ }^{8}$ and in the stories in this collection),

8 See for example the lengthy description of the painting in the People's Palace in Glasgow in which David professes to have seen the face of a black slave which has since been painted over, or that of the "painted men of power" which Le Fleur admires to the extent that he visualises himself "boldly supplant[ing] Cecil John Rhodes himself." (David's Story, 191-93 and 149 respectively.) See also in this collection the detailed and vivid description of the Doulton Fountain in Glasgow which forms the backbone of the story "There's the Bird that Never Flew." (65-79) 
barely evokes it here, except for a brief description of a trompe l'œil window, used to stress Bev's secret desire to write and create her own "momentary deception of the eye." (128) The trompe l'œil then emerges in Roddy's story, which reveals the masquerade of Gavin and Bev's happy marriage as well as Gavin's cruelty towards his wife. The strong imagery with which the narrator describes Gavin's reaction to this part of Roddy's story ("Gavin sits bolt upright in his chair as the monstrous thing claws its way out of the print, and hisses," 130) underscores the power of representation, and the reference to the monster is particularly significant in terms of its etymological implications (from the Latin monstrum or monstrare, meaning to teach and to show respectively). Here the roles are reversed, and Gavin, the academic who has revelled in dishing out lessons to Roddy, is no longer the professor but the pupil. Yet the intrusion of the narrator in the midst of a paragraph full of rhetorical questions posed by Gavin to state that "[ $t]$ he thing slithers under Bev's chair where it hides" (131) playfully hints at a third trompe l'œil. After a break in the text, a question opens the final part of the story: "Why did Bev give the offensive story to Gavin?" (131), yet it is impossible to determine categorically to whom this question should be attributed. The use of the adjective "offensive," and the fact that the previous paragraph is narrated from Gavin's point of view might indicate that this question should be attributed to Gavin. The fact that the following paragraph, which provides a partial response to this question, is narrated from Bev's point of view may, on the other hand, indicate that it is Bev's. One might also consider that the narrator intrudes to ask a rhetorical question which the reader has necessarily been musing over. The previously clear-cut narrative levels and points of view blur at this point, and culminate in the final paragraph of the story which is typographically separated from the paragraph preceding it and the margin inset, in the manner of the excerpts from Roddy's story, but which is not italicised as the excerpts have been. The paragraph lyrically describes from a male point of view a woman lifting a glass paper-weight, and throwing it against the french windows which shatter, revealing "a full trompe l'œil moon." (133) One is therefore left to consider the implications of this inserted text. Either one reads it as the final paragraph of Roddy's story, which Gavin is preparing to read in the preceding paragraph, in which case the absence of italics might signal the move from the embedded narrator's representation of "something real," (131) to a "fictional" or imagined ending. One may alternatively consider that the elaborate description of this moment of rebellion on the part of the mild-mannered Bev is her own composition finally come to fruition, or perhaps even an element of the central diegesis, inserted by the narrator who maintains ultimate control of all the narrative layers of this story. Ultimately, however, these questions remain unanswered, and are fruitless in any case, since what is significant is the opening up of perspectives in this short story, in which narrative levels become so intertwined as to become inextricable, thus undermining the totalising nature of the single story. Furthermore, aside from exploring the question of representation, this story also highlights the emergence 
of significant counter-discourses which, through fiction, have the potential to unsettle colonial (or even postcolonial) dominant discourses. By opening up and rendering ambivalent the ending of this particular short story, which so overtly interrogates the aftermath of Apartheid and the gulf which continues to separate individuals, Wicomb undermines Rainbow Nation rhetoric, while privileging the necessity of giving voice to a multiplicity of narratives.

Zoë Wicomb is certainly not the first short story writer to incorporate a postmodern interrogation of the totalising nature of narrative into her stories, but what perhaps makes this collection so innovative is the marriage of this postmodern technique with the short story cycle. Although Maggie Dunn and Ann Morris have expressed concern at the use of the term "short story cycle," claiming that "the term [...] is doubly problematic: it not only implies inferior status in the generic hierarchy, but also prescribes or at least suggests generic limitation," (Dunn \& Morris 5) I would contend firstly that dismissing the short story as having an "inferior status" in relation to the novel only entrenches "generic hierarchy." But more importantly, far from creating generic limitations, the short story cycle actually contributes to opening up the genre, and, as Lynch has pointed out, "subvert[ing] the impression of completion, of closure and totality." (Lynch 18) The fact that the stories in Wicomb's collection are only loosely connected, both through place and character, further enhances the disunity in the unity. Her calling attention to the fictional nature of her characters has the same effect when, at the end of the title story "The One that Got Away," a first person narrator suddenly emerges and recounts a conversation she has with one of the characters in the story, asking him what he thinks of the story she has made up about him. This is all the more interesting as the title of the story is a well-known cliché which alludes to something which one cannot pin down. By inserting this conversation at the end of the story, Wicomb undermines the cliché, and emphasises the "Chinese boxes" (50) effect. The "real" (but still fictional) Drew's query about "where [it will] all end" (50) suggests that the answer is that there is no end, only "the perspective of infinite regress." (Bal 58) There will always be "the one that got away," that cannot be pinned down through language, and the horizons of the short story are therefore posited by Wicomb as perpetually receding, offering potentially endless possibilities of representation and interpretation.

Fiona McCANN

Université de Lille 3

\section{Works Cited}

Adichie, Chimamanda Ngosi. "The Danger of a Single Story." TedTalks. Available online http://www.ted.com/talks/ chimamanda_adichie_the_danger_of_a_single_story.htm. Consulted Nov 122009. 
Bakhtin, Mikael. The Dialogic Imagination: Four Essays by M.M. Bakhtin. Trans. Caryl Emerson and Michael Holquist. 1981. Austin : U of Texas P, 2004.

BAL, Mieke. Narratology: Introduction to the Theory of Narrative. Trans. Christine Van Boheemen. 1985. Toronto: U of Toronto P, 1997.

Boyce Davies, Carole. Black Women, Writing and Identity: Migrations of the Subject. New York, London: Routledge, 1994.

Chamoiseau, Patrick, and Édouard Glissant, Quand les murs tombent: l'identité nationale hors-la-loi? Paris: Éditions Galaade, 2007.

Dunn, Maggie, and Ann Morris. The Composite Novel: The Short Story Cycle in Transition. Toronto: Maxwell Macmillan, 1995.

Genette, Gérard. Discours du récit. 1972. Paris: Éditions du Seuil, 2007.

Glissant, Édouard. Traité du Tout Monde. Paris: Gallimard, 1997.

LewIS, Desirée. Living on a Horizon: Bessie Head and the Politics of Imagining. Trenton, NJ \& Asmara, Eritrea: Africa World P, 2007.

Lynch, Gerald. The One and the Many: English-Canadian Short Story Cycles. Toronto: U of Toronto P, 2001.

Meyer, Stephan, and Thomas Olver. "Zoë Wicomb interviewed on Writing and Nation." Journal of Literary Studies 18. 2 (2002): 182-219.

Sicherman, Carole. "Afterword." You Can't Get Lost in Cape Town. By Zoë Wicomb. New York: The Feminist P, 2000.

Wiсомв, Zoë, The One That Got Away. Cape Town: Umuzi, 2008.

-. Playing in the Light. New York: The New P, 2006.

—. David's Story. New York: The Feminist P, 2001.

-. You Can't Get Lost in Cape Town. 1987. New York: The Feminist P, 2000. 